\title{
Professionalism of the Female Teacher at Riau Palm Oil Plantation Sumatera Indonesia
}

\author{
Mesta Limbong
}

\begin{abstract}
This research shows professionalism of the female teachers at palm oil plantation's school which belongs to Astra Agro Lestari Company $18 \%$ of the Astra Agro Lestary company's employees is female, and some of them work as a teacher.

Teacher's professionalism is considered important to be investigated because by professionalism, teachers can perform their best to serve the need of education for their students. Individually, female teacher holds double tasks as a mother in their family and as a female teacher professionally.

Research method of this research is descriptive quantitative with the total of the sample is 48 female teacher. In collecting the data, researcher used questionnaire.

The result of the research shows that female teachers in the Astra Agro Lestary company's palm oil plantation has worked professionally according to their tasks. Focus Group Discussion result and based on the data analysis, the researcher found out that female teacher who hasn't married yet shows a dynamic behavior on technology development in teaching compares to the one who has married. Female teacher owns a primary task as a teacher and an additional task, helping the company in assisting the society internally and externally. The additional task is training and assisting maternal and child health services workers, introducing the central trash disposal to the society, assisting the community, assisting the day care workers, doing an assistance to the parents about the importance of breast milk feeding, and stimulating the mothers in following the family welfare programme activities.
\end{abstract}

Keywords: Professionalism; Female Teacher; Palm Oil Plantation.

\section{INTRODUCTION}

H.A.R Tilaar, one of Indonesian education experts, from his work on our teacher: character and intelligence artist which is published in 2016, openly explained the role of teachers since past education, in the independence period, the teacher's job and the future of it, and also Indonesian teachers with various strategies in making the future generations characterized $^{\text {i }}$

Teacher, who works in palm oil plantations in Indonesia, becomes one of indicator that reflects the number of children in school age and number of teachers who teach in hinterland. In Atra Agro Lestari , 60 schools such as: 37 Kindergartens, 13 elementary schools and 10 junior high schools have received training with a total of about 428 teachers belongs to Astra Agro Lestari Company . 18\% of

Revised Manuscript Received on September 22, 2019

Mesta Limbong, Universitas Kristen Indonesia, Mayjen Sutoyo No. 2, Cawang, East Jakarta, Indonesia. mesta.limbong@uki.ac.id the Astra Agro Lestari Company's employees is female, and some of them work as a teacher. ${ }^{\text {ii }}$

There are problems which are faced by teachers in palm oil plantations such as, the opportunity to participate in training activities conducted by the government is very limited, because of the number of participants is limited. Even though the teachers have fulfilled the national standards with their educational background, they still require an upgrade for their knowledge. If the five-year work period does not get the opportunity to be upgraded, the knowledge will be obsolete and will not in the same path with the recent development of the teachers' knowledge without a doubt.

Based on the Teacher and Lecturer Statute No. 14 of 2005 in article 1 paragraph 4 , describes that professional is a work or an activity that done by a person and becomes a source of income requires an expertise, an ability, or a skill that meets a certain standards or norms and also requires a professional education. ${ }^{\text {iii }}$

A female teacher with her double role in her life will find it hard to pursue her career different than a male teacher, because of the commitment in handling individual needs, family and work at the same time. This condition may be experienced by other female teachers, but the level of difficulty in doing it as a teacher and a plantation's worker in the same time certainly is not the same compare with those who are not.

How is the image of the professionalism of female teachers in palm oil plantations of Astra Agro Lestari, in Riau Sumatra Indonesia? Is there a difference between female teachers who are married to those who are not married in the palm oil plantation Astra Agro Lestari Company's in Riau Sumatra? What kinds of efforts have been made to increase the professionalism of female teachers in palm oil plantations of Astra Agro Lestari Company's in Riau Sumatra Indonesia?

\section{Literature REVIEW}

Young teachers who have the opportunity to give services for the schools in the border of Indonesia - Malaysia, in the area of the palm oil plantation in Kinibalu, express their experiences while carrying out their duties, they experience difficulties such as: lack of clean water, locations which are far from the city, and limited facilities. Their enthusiasm and desire to improve the nation's future generation at other regions, keep them enthusiastic in carrying out their duties and works. ${ }^{\text {iv }}$ 
Kompas January 19th, 2018 explained that there are a large number of bachelor educations, and they still have to attend the teacher professional education ${ }^{\mathrm{v}}$. This new policy makes those who have completed the first strata education cannot directly become teachers, they have to attend education to complete their profession. In other words, the professionalism of teachers is not good enough if only with the educational background that they already have, they still need to develop themselves by following programs from schools, from the regional and central education office.

Female teachers who carry out an assignment in the palm oil plantations have their own difficulties. Such as: is not easy to get out of the plantation because of limited access and transportation. In statute No. 14 of 2005 concerning Teachers and Lecturers, defines that what is meant by teacher is a professional who educates, teaches, guides, directs, trains, gives score and evaluates the students from the early age, formal education, basic education, and

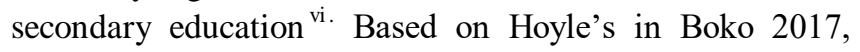
"professionalism as a term used to describe enhancement of the quality of service". Another opinion regarding the professionalism from Boyt Lusch and Naylor which is still in Boko, that professionalism consists of the attitudes and behavior one possesses toward one's professions. It is an attitudinal and behavioral orientation that individuals possess toward their occupations vii . Linda Evan "professionalism not as absolute or an ideal, but as a sociality construct, contextually variable and contested concept. Defined by management and expressed in its expectations of workers and the stipulation of task they will perform ${ }^{\text {viii. }}$

It can be concluded that professionalism relates with attitude, ability, skill, behavior, and an expression of daily activities that is carried out by a person related to responsibility of professionalism.

\section{Methodology/Materials}

\section{A. Research Method}

The study was conducted on palm oil plantations in Sumatra's Riau region from November 2018 to December 2018. The samples were female teachers who are married and who are not. The collecting data process was done by filling out questionnaire and supplementary information through focus group discussion.

\section{B. Research Design}

This research refers to Miles and Huberman opinion ${ }^{\text {ix }}$. The pre-research stage initially was carried out by conducting literature studies, drafting. Then, in conducting the research, questionnaires and focus group discussion were prepared as a complementary of the data. The result was analyzed, and the findings were described in the discussion and finally made a conclusion from the research findings.

\section{RESUltS AND FINDINGS}

\section{A. Description of Research Background}

Research on female teachers from several schools in the area of oil palm plantations in the Riau region which is managed by Astra Agro Lestari has a total sample of 48 respondents. The number of female respondents (teachers) who have a family is $84 \%$ and the other $16 \%$ female teachers don't have a family. They have worked for more than 5 years, and also have diploma or bachelor's degree.

\subsection{Portrait of Female Teacher Professionalism}

$98 \%$ of respondents strongly agree that their work is fit with their expertise, improve the skills, improve their profession, and increase the intensity of self-development and about $2 \%$ of respondents say they do not agree or lack of willingness to develop themselves.

$68 \%$ of respondents realized that discipline strongly supports the teaching assignments. Generally, plantation environment emphasizes discipline in carrying out tasks and work rhythm and their expertise, just like in the school. Teachers have skills other than their basic knowledge which form the fundamental when they become teachers based on their field / expertise. For example, teaching Christian subject is also expected to be able to play musical instruments, because the respondents are expected to participate in church activity, as well as other teachers. For example, have the skills to assist students in doing extra-curricular activities, such as: dancing / art, sports. Discipline is one of indicator that has an impact on the quality of educating people ${ }^{\mathrm{x}}$.

$96 \%$ of respondents strongly agree to conduct an analysis and find solutions to handle problems happened at school and find solutions to every problem. $94 \%$ of respondents also have high concentration in doing their duties, $84 \%$ work precisely and correctly and $89 \%$ work without burden.

\section{Pic 1. Concentration, on time, without burden}

Respondents have the skills and commitment to carry out their duties, make a priority, the ability to manage the time and do their tasks without feeling of any pressure.

$92 \%$ of respondents strongly agree to make a report, to have work skills and to be transparent with the data from every activity and to make the documentation of it. These are needed to support the documentation for accreditation and monthly reports and as a report to school coordinator, while $6 \%$ of respondents sometimes make the report,

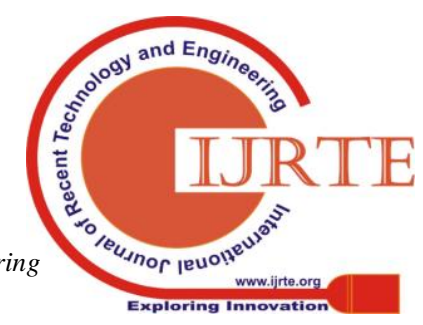


$2 \%$ do not answer at all.

Pic 2. Work ethic

$79 \%$ of respondents plan to take part in profession education activities, $21 \%$ still have a doubt whether they need to take professional education or not. Because of tight schedule of teaching and extra-curricular activities, it is difficult for the teacher to take part in professional education.

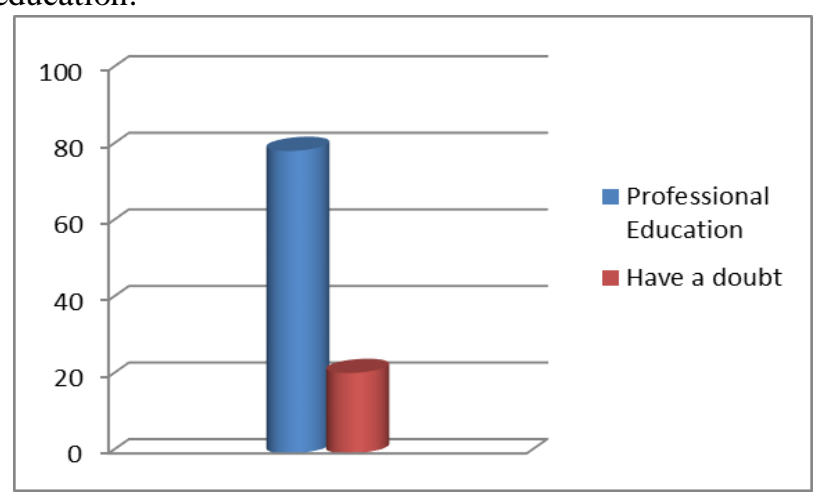

Pic 3. Professional education

$75 \%$ of respondents read things that related to the profession, $23 \%$ of respondents sometimes read things that related to their profession and $2 \%$ of respondents said that they did not need to read things that related to the profession.

Quizizz.com was conducted during focus group discusstion activities. The result is eight unmarried female teachers $(16 \%)$ who often use the media that is shown, know how to use it. The observation results provide information that unmarried female teachers are more dynamic and have the ability to use technology to support learning activities.

The overall portrait of female teachers can be said is professional workers. The teachers have done and prepared themselves to work professionally, such as: being discipline, finding solutions for problems at school, discussing and developing themselves with various fixed internal and external activities, making reports, paying attention to ethical signs and universal values, and developing themselves by reading.

The difference in able to use learning media between female teachers who already married and unmarried, can be overcome by debriefing or enrichment of the material related to the learning media. Teachers are agents of change and teacher's roles are irreplaceable (Kompas, 25/11/2015, Kompas 2/12/2018) $)^{\mathrm{xi}}$.

Female teachers as corporate partners carrying out social activities in the external and internal environment, such as: gardening, making waste banks, providing information about the importance of breastfeeding for babies, conducting Family Welfare Education activities .

\section{Suggestion}

- $\quad$ Providing opportunities for a development of female teacher professionalism at palm oil plantation which belongs to Astra Agro Lestari in Riau Sumatra Indonesia.

- Mentoring and enrichment for female teacher's so they can use varied method for teaching.

- Schools explore opportunities for teachers to take part in activities related with their profession according to government regulations which has been adjusted with the conditions of female teachers in oil palm plantations.

\section{REFERENCES}

[1] Kompas. January 2018. Calon Guru Melimpah. Jakarta: Kompas, page 1.

[2] Kompas. 2015. Guru, Agen Perubahan bangsa. p 1.

[3] Boko, K. S. (2017). THE EVALUATION OF TEACHER PROFESSIONAL DEVELOPMENT PROGRAM IN BUIN BATU JUNIOR HIGH SCHOOL, WEST SUMBAWA. Journal of Education Research in Administration and Management (JERAM)(1), 17\%V 11.

[4] Joko, S. (2018). Laporan Bulanan Tiap Sekolah. Riau: PT Astra Agro Lestari Tbk.

[5] Limbong, M. (2017). THE ROLE OF CORPORATE SOCIAL RESPONSIBILITY IN QUALITY IMPROVEMENT OF 9-YEAR EDUCATION. Journal of Education Research in Administration and Management (JERAM)(1), 11\%V 11.

[6] Miles, M. B., \& Huberman, A. M. (1984). Qualitative data analysis : a sourcebook of new methods. Beverly Hills: Sage Publications.

[7] Prabowo, W. H. (2018, December 2). Peran Guru Tak Tergantikan, Kompas, p. 1.

[8] Tilaar, H. A. R. (2016). Guru Kita: artis karakter \& kecerdasan. Yogyakarta: Lamatera.

[9] UNDANG-UNDANG SISTEM PENDIDIKAN NASIONAL. (2013). Bandung: FOKUSMEDIA.

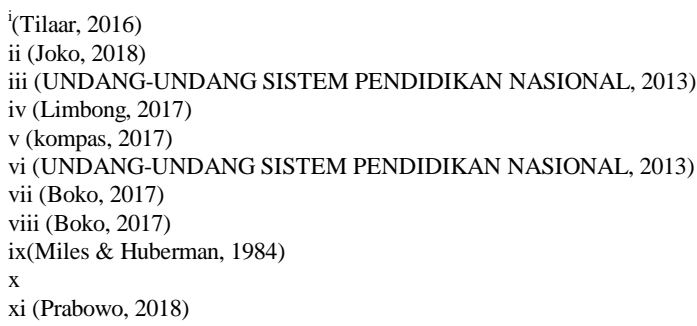

\section{AUTHORS PROFILE}

My name is Mesta Limbong, I am orking in Universitas Kristen Indonesia, Mayjen Sutoyo No. 2, Cawang, East Jakarta, Indonesia.my area of ineterst is education. 